As dentists we often know what is clinically right

for our patients yet they may choose to ignore our

recommendations. . .

\title{
Are we guilty of unethical selling?
}

In my last leader I looked at the topic of selling ethically, what it means and why it is so important for the provision of comprehensive patient care. My definition of ethical selling was identifying a situation where the dental practice can provide a service for the patient that matches the patient's requirements. I placed the emphasis on the identification of the situation (clinical or non-clinical) because the focus of all ethical selling, as with all patient care, must be on the patient.

This focus contrasts with unethical selling which focuses much more on the requirements of the salesperson - the need to make a sale. Thus unethical selling is more about persuasion to try and obtain the sale, usually without any thought about whether the potential customer wants or needs the product or service. We have all suffered in an unethical sales situation, whether it be timeshare, life insurance or double glazing (to name three clichés) and usually recognize when it is happening. But are there less obvious examples?

Unethical selling occurs if we are sold an inappropriate insurance policy (which pays the salesperson a higher commission) when we want some form of income protection in the event of illness or accident It is the same when a company uses fear to persuade vulnerable people to purchase an expensive burglar alarm or fit expensive locks on their doors. Unethical selling can come in many guises, and sometimes the line between an ethical and an unethical approach can be very fine indeed.

For example, consider insurance again. Suppose that, in the opinion of the salesperson, an individual genuinely needs some form of life insurance to protect his income in the event of his untimely death. A young man with a good salary, a wife who is not working and three children below the age of 10 is the most typical example. If the man has made no provision to cover his family's loss of income in the event of his death then we could say there is a desperate need. Premature death would have a devastating effect on his entire family. But suppose the man refuses to purchase life insurance of any kind? How much persuasion, if any, should the salesperson apply to try and persuade the man to buy an appropriate policy?

If we believe that the responsibility of the salesperson is simply to make the family aware of the problem and the family decides to take the risk then any form of persuasion by the life insurance salesman is starting to move towards unethical selling, is it not? Yet this example illustrates the difficulty insurance salespeople may sometimes be faced with when people apparently do not appreciate the effects of their actions.

of course the same is true for the health professions. As dentists we often know what is clinically right for our patients yet they may choose to ignore our recommendations, especially if those recommendations involve substantial costs to them. If we begin to try and persuade them to buy our treatment recommendations, are we not doing the same as the insurance example above?

This whole subject raises an interesting question how far can we go ethically in trying to persuade people to buy our suggested service (oral care) based on need? The whole subject of oral health promotion is based on need, and more importantly on the need as perceived by the oral health professional. It is exactly the same as the example above about insurance. Where do we draw the line on persuasion techniques (as opposed to simple information provision)? How ethical are we if we believe the ends justify the means? And who decides anyway what 'the ends' should be?

I find this whole topic both disturbing and fascinating at the same time. At times I think all forms of persuasion (whatever the apparent justification) are unethical, and at other times I appreciate any attempt to persuade people to seek out oral care because of my own need to provide effective oral health for people.

So are we guilty of unethical selling at times? The answer is not always as obvious as you'd think.

Mike Grace

m.grace@bda-dentistry.org.uk 